\title{
Modeling lactose hydrolysis for efficiency and selectivity: Toward the preservation of sialyloligosaccharides in bovine colostrum whey permeate
}

\author{
Juliana M. L. N. de Moura Bell, ${ }^{\star} \dagger$ Leticia F. M. C. Aquino, $\ddagger$ Yan Liu, ${ }^{*}$ Joshua L. Cohen, ${ }^{*}$ Hyeyoung Lee, ${ }^{* 1}$ \\ Vitor L. de Melo Silva, $\ddagger$ Maria I. Rodrigues, $\S$ and Daniela Barile* $\dagger^{2}$ \\ *Department of Food Science and Technology, and \\ †Foods for Health Institute, University of California, Davis, One Shields Avenue, Davis 95616 \\ ‡Department of Food Science and Technology, Universidade Federal Fluminense, Niteroi, Rio de Janeiro, 24230340, Brazil \\ §Protimiza Consulting and Training in Experimental Design and Process Optimization, Campinas, SP, 13000 000, Brazil
}

\section{ABSTRACT}

Enzymatic hydrolysis of lactose has been shown to improve the efficiency and selectivity of membranebased separations toward the recovery of bioactive oligosaccharides. Achieving maximum lactose hydrolysis requires intrinsic process optimization for each specific substrate, but the effects of those processing conditions on the target oligosaccharides are not well understood. Response surface methodology was used to investigate the effects of $\mathrm{pH}(3.25-8.25)$, temperature $\left(35-55^{\circ} \mathrm{C}\right)$, reaction time (6 to $58 \mathrm{~min}$ ), and amount of enzyme $(0.05-0.25 \%)$ on the efficiency of lactose hydrolysis by $\beta$-galactosidase and on the preservation of biologically important sialyloligosaccharides ( $3^{\prime}$-siallylactose, $6^{\prime}$-siallylactose, and $6^{\prime}$-sialyl- $N$-acetyllactosamine) naturally present in bovine colostrum whey permeate. A central composite rotatable design was used. In general, $\beta$-galactosidase activity was favored at $\mathrm{pH}$ values ranging from 3.25 to 5.75 , with other operational parameters having a less pronounced effect. $\mathrm{A} \mathrm{pH}$ of 4.5 allowed for the use of a shorter reaction time (19 min), lower temperature $\left(40^{\circ} \mathrm{C}\right)$, and reduced amount of enzyme $(0.1 \%)$, but complete hydrolysis at a higher $\mathrm{pH}(5.75)$ required greater values for these operational parameters. The total amount of sialyloligosaccharides was not significantly altered by the reaction parameters evaluated, suggesting specificity of $\beta$-galactosidase from Aspergillus oryzae toward lactose as well as the stability of the oligosaccharides at $\mathrm{pH}$, temperature, and reaction time evaluated.

Received February 21, 2016.

Accepted April 5, 2016.

${ }^{1}$ Present address: Division of Metrology for Quality of Life, Korea Research Institute of Standards and Science, Yuseong, Daejon 34113, Republic of Korea.

${ }^{2}$ Corresponding author: dbarile@ucdavis.edu
Key words: lactose hydrolysis, sialyloligosaccharides, colostrum

\section{INTRODUCTION}

Bovine milk and dairy streams such as whey permeate have been identified as sources of bioactive oligosaccharides that are structurally identical/similar to the oligosaccharides present in human milk. Recently identified milk oligosaccharides in bovine whey permeate contain branched oligosaccharides decorated with sialic acid and fucose (Barile et al., 2009, 2010), exhibiting greater similarity to human milk oligosaccharides than currently available prebiotics such as inulin and galacto-oligosaccharides (Barile and Rastall, 2013). The recovery of highly bioactive oligosaccharides from whey permeate, a co-product from the removal of whey proteins during ultrafiltration, has the added potential to mitigate environmental and economic problems associated with the disposal of this underutilized dairy stream.

The major challenge in isolating oligosaccharides from dairy streams is to enrich oligosaccharides while simultaneously reducing the content of lactose and other simple sugars that do not possess the desired prebiotic or protective functions and that would confound the biological activity of oligosaccharides for in vitro testing. The high lactose content (44-52 g/L; Jelen, 1979) and the low concentration of the most abundant sialyloligosaccharides in bovine milk $(0.033 \mathrm{~g} / \mathrm{L}$; Martín-Sosa et al., 2003), in addition to their molecular weight proximity, demonstrates the processing challenge associated with the recovery of oligosaccharide fractions with a high degree of purity when using membrane techniques.

Upstream lactose hydrolysis by $\beta$-galactosidases has been shown to improve the efficiency and selectivity of membrane-based separations toward the recovery of biologically bioactive oligosaccharides (Sarney et al., 
2000). Nearly $100 \%$ lactose hydrolysis was achieved when $\beta$-galactosidase from Aspergillus oryzae was incubated in human milk at $\mathrm{pH} 5.2$ for $4-5 \mathrm{~h}$. The combination of selective protein precipitation, lactose hydrolysis, and nanofiltration (followed by diafiltration) enabled the recovery of more than $50 \%$ of the human milk oligosaccharides (Sarney et al., 2000). However, residual lactose and monosaccharides remained in the retentates produced by this approach, which when concentrated by membrane filtration often became more concentrated than the target oligosaccharides, thus markedly reducing the purity of the final product.

The objective of the present work was to maximize the efficiency of lactose hydrolysis by $\beta$-galactosidase while achieving maximum preservation of biologically important sialyloligosaccharides $\left(3^{\prime}\right.$-siallylactose $\left[\mathbf{3}^{\prime}\right.$ SL], 6 '-siallylactose $\left[\mathbf{6}^{\prime}\right.$-SL], and $6^{\prime}$-sialyl- $N$-acetyllactosamine $\left[\mathbf{6}^{\prime}\right.$-SLN] $)$ naturally present in bovine colostrum whey permeate. We chose to use bovine colostrum to facilitate the analytical quantification of oligosaccharides, but this approach is easily translatable to more typical dairy streams derived from cheese-making. This investigation is of great importance to maximizing the purity and yield of acidic oligosaccharides when considering downstream isolation by membrane filtration. In the present work, the effects of $\mathrm{pH}$, temperature, reaction time, and amount of enzyme were simultaneously evaluated. To identify the ideal combination of $\mathrm{pH}$, reaction time, temperature, and amount of enzyme, a central composite rotatable design totaling 28 experimental conditions was used.

\section{MATERIALS AND METHODS}

\section{Bovine Colostrum Whey Permeate}

Bovine colostrum whey permeate was kindly provided by La Belle Colostrum (Bellingham, WA). Liquid colostrum was initially defatted via cream separators and decaseinated by rennet addition. The whey obtained after the removal of caseins was pasteurized at $63^{\circ} \mathrm{C}$ for $30 \mathrm{~min}$. Whey proteins were removed by ultrafiltration (10-kDa membrane) under continuous diafiltration to produce whey permeate. Lactose and solid contents of the colostrum whey permeate (starting material) were $17.4 \pm 0.62 \mathrm{~g} / \mathrm{L}$ and $3.15 \pm 0.03 \%$, respectively.

\section{$\beta$-Galactosidase Treatment of Bovine Colostrum Whey Permeate}

A food-grade fungal lactase (Bio-Cat Inc., Troy, VA) derived from the fungus A. oryzae was used to hydrolyze lactose into $\beta$-D-galactose and $\alpha$-D-glucose.
Table 1. Variables and levels evaluated in the experimental design to optimize lactose hydrolysis efficiency by $\beta$-galactosidase and preservation of acid oligosaccharides ${ }^{1}$

\begin{tabular}{lccccc}
\hline & \multicolumn{5}{c}{ Level } \\
\cline { 2 - 6 } Variable & $-\alpha$ & -1 & 0 & 1 & $+\alpha$ \\
\hline pH, $X_{1}$ & 3.25 & 4.5 & 5.75 & 7.0 & 8.25 \\
Time (min), $X_{2}$ & 6 & 19 & 32 & 45 & 58 \\
Temperature $\left({ }^{\circ} \mathrm{C}\right), X_{3}$ & 35 & 40 & 45 & 50 & 55 \\
Enzyme $(\%), X_{4}$ & 0.05 & 0.10 & 0.15 & 0.20 & 0.25 \\
\hline
\end{tabular}

${ }^{1}$ Complete $2^{4}$ factorial design parameters, with 4 independent variables in 2 levels, 4 repetitions in the central point, and 8 axial points.

Thirteen milliliters of whey permeate was adjusted to 3.25 to $8.25 \mathrm{pH}$ with $0.1 \mathrm{~N} \mathrm{HCl}$ or $0.1 \mathrm{~N} \mathrm{NaOH}$, and $\beta$-galactosidase was added to achieve 0.05 to $0.25 \%$ (wt/wt) (Table 1). Whey permeate samples were incubated at 35 to $55^{\circ} \mathrm{C}$ for 6 to $58 \mathrm{~min}$ (Table 1) at $50 \mathrm{rpm}$ in $250-\mathrm{mL}$ Erlenmeyer flasks. After lactose hydrolysis, samples were immediately centrifuged at $3,900 \times g$ for 30 min using a $30-\mathrm{kDa}$ molecular weight cutoff centrifugal filter device (Amicon Ultra-15 Centrifugal Filter, Millipore, Billerica, MA) to separate the enzyme from the hydrolyzed fraction. Unequal permeate volumes due to the addition of different amounts of $\mathrm{HCl}$ or $\mathrm{NaOH}$ used during the $\mathrm{pH}$ adjustment step were equalized by the addition of distilled water to achieve a uniform final volume. Samples from all experiments were analyzed for glucose, galactose, lactose, 3'-SL, 6'-SL, and 6'-SLN.

\section{Experimental Design and Statistical Analysis}

Response surface methodology was used to investigate the optimal reaction parameters affecting the efficiency of lactose hydrolysis by $\beta$-galactosidase and the preservation of the major oligosaccharides present in bovine colostrum whey permeate. The use of a factorial design methodology, associated with response surface analysis, enables simultaneous analysis of multiple variables, thus reducing processing time and costs. The individual and combined effects of the most important parameters that affect $\beta$-galactosidase activity $(\mathrm{pH}$, reaction time, temperature, and amount of enzyme) were evaluated by a central composite rotatable design, with 4 central points and 8 axial points (Hatzinikolaou et al., 2005; Rodrigues and Iemma, 2014). The total number of experiments followed the equation $2^{k}+2 k$ $+n_{\mathrm{c}}$, where $k$ is the number of independent variables and $n_{\mathrm{c}}$ is the number of repetitions in the central point.

The effects of $\mathrm{pH}(3.25-8.25)$, temperature $\left(35-55^{\circ} \mathrm{C}\right)$, reaction time (6-58 $\mathrm{min})$, and amount of enzyme (0.05$0.25 \% \mathrm{wt} / \mathrm{wt})$ on the efficiency of lactose hydrolysis 
by $\beta$-galactosidase and preservation of sialyloligosaccharides were evaluated. The independent variables $(\mathrm{pH}$, reaction time, temperature, and amount of enzyme) were evaluated according to coded levels $(-\alpha$, $-1,0,+1,+\alpha$; Table 1$)$. The reaction kinetics could have been evaluated for each experimental condition, but the relatively short reaction time, the large number of analytic measurements, and the model validation in which samples were withdrawn at 15-min intervals during $1 \mathrm{~h}$ justified the use of the variable reaction time as an independent variable. The model validation allowed for further evaluation of the reaction kinetics under conditions at which lactose hydrolysis was optimal. The variable levels used in the experimental design were selected based on preliminary tests performed by our group (data not shown). Central points are the average of levels -1 and +1 , and axial points were determined by interpolation $(\alpha= \pm 2.0)$. Coded and uncoded levels and their corresponding independent variables are shown in Table 1. Dependent variables (i.e., evaluated response) were the percentage of lactose hydrolysis and the quantification of acidic oligosaccharides. Data were analyzed by the Protimiza Experiment Design Software (http://experimental-design.protimiza.com.br). The significance of the model was tested by ANOVA.

\section{Quantification of Simple Sugars (Lactose, Glucose, and Galactose) and Complex Oligosaccharides in Bovine Colostrum Whey Permeate}

Simple sugars and the major complex oligosaccharides (3'-SL, 6'-SL, and 6'-SLN) were determined by high-performance anion-exchange chromatography with pulsed amperometric detection (HPAEC-PAD ICS-5000+; Thermo Scientific, Sunnyvale, CA). Calibration curves $\left(\mathrm{R}^{2}>0.999\right)$ were prepared with $3^{\prime}-\mathrm{SL}$, 6'-SL, and 6'-SLN (V-Labs, Covington, LA) for oligosaccharide analysis and glucose, galactose, and lactose (Sigma, St. Louis, MO) for simple sugar determination. Whey permeate samples were diluted 10 to 1000 times and filtered through a $0.2-\mu \mathrm{m}$ membrane (Acrodisc 13mm PES, Pall Life Sciences, Port Washington, NY). For monosaccharide analysis, a $25-\mu \mathrm{L}$ aliquot was injected into a Carbo-Pac PA10 (Dionex, Sunnyvale, $\mathrm{CA}$ ) column at $1.2 \mathrm{~mL} / \mathrm{min}$ flow rate, with an isocratic eluent of $10 \mathrm{~m} M \mathrm{NaOH}$ for $12 \mathrm{~min}$ and a gradient up to $100 \mathrm{~m} M$ for the next $12.5 \mathrm{~min}$. For oligosaccharide analysis, a $25-\mu \mathrm{L}$ sample was injected into a Carbo-Pac PA200 (Dionex) column with an isocratic eluent at 0.5 $\mathrm{mL} / \mathrm{min}$ of $10 \mathrm{~m} M$ sodium acetate in $100 \mathrm{~m} M$ sodium hydroxide. Experiments were conducted in triplicate. Lactose hydrolysis (\%) was calculated as described in equation 1 :

$$
\begin{aligned}
& \text { Lactose hydrolysis }(\%)= \\
& \left(\frac{\text { Initial amt lactose }- \text { Residual amt lactose }}{\text { Initial amt lactose }}\right) \times 100 \text {. }
\end{aligned}
$$

The total amount (amt) of oligosaccharides of each experimental condition, representing the sum of 3 '-SL, 6'-SL, and 6'-SLN, was analyzed by the Protimiza Experiment Design Software with the objectives of assessing the specificity of $\beta$-galactosidase toward the acidic oligosaccharides and of gaining a better understanding of the effects of the processing conditions used $(\mathrm{pH}$, reaction time, and temperature) on the target oligosaccharides. A comparison between the experimental data and control values was performed.

\section{RESULTS AND DISCUSSION}

\section{Lactose Hydrolysis Optimization}

Simultaneous interaction of significant independent variables and their optimum levels were evaluated by the central composite design. The effects of $\mathrm{pH}$, reaction time, temperature, and amount of enzyme (\%) on lactose hydrolysis efficiency and preservation of important sialyloligosaccharide structures that are common to bovine and human milk (3'-SL, 6'-SL, and 6'-SLN) are shown in Table 2.

$\beta$-Galactosidase activity was greatly affected by $\mathrm{pH}$ values, with acidic conditions favoring lactose hydrolysis. Our results are in agreement with manufacturer specifications and experimental data regarding the use of different brands of commercially available $\beta$-galactosidases from $A$. oryzae, for which enzyme activity is usually optimal in the $\mathrm{pH}$ range of 4.5-5.0 (Czermak et al., 2004). In general, $\beta$-galactosidase activity was reduced at $\mathrm{pH}$ values ranging from 5.75 to 8.25 , with other operational parameters having a less pronounced effect. The lowest lactose hydrolysis (33\%) was observed at the highest $\mathrm{pH}$ value (8.25) and at intermediate values for reaction time (32 $\mathrm{min})$, temperature $\left(45^{\circ} \mathrm{C}\right)$, and amount of enzyme $(0.15 \%)$. Complete lactose hydrolysis $(100 \%)$ was obtained at $\mathrm{pH}$ values ranging from 3.25 to 5.75 . A pH of 4.5 allows for the use of shorter reaction times (19-45 min), lower temperatures $\left(40-50^{\circ} \mathrm{C}\right)$, and reduced amounts of enzyme (0.1-0.2\%), but complete hydrolysis at higher $\mathrm{pH}(5.75)$ requires greater values for these parameters. The comparison of the results herein with published literature is challenging because of the differences in substrate composition, reaction mode (batch or continuous), mode of enzyme use (free or immobilized), or the purpose of the work. For example, 4 to $5 \mathrm{~h}$ of incubation time was 
Table 2. Experimental design for optimizing the hydrolysis of lactose from bovine colostrum whey permeate by $\beta$-galactosidase and preservation of acidic oligosaccharides ${ }^{1}$

\begin{tabular}{|c|c|c|c|c|c|c|c|c|}
\hline Treatment & $\begin{array}{l}\mathrm{pH} \\
\left(X_{1}\right)\end{array}$ & $\begin{array}{c}\text { Time }(\min ) \\
\left(X_{2}\right)\end{array}$ & $\begin{array}{c}\text { Temperature }\left({ }^{\circ} \mathrm{C}\right) \\
\left(X_{3}\right)\end{array}$ & $\begin{array}{c}\text { Enzyme }(\%) \\
\left(X_{4}\right)\end{array}$ & \multicolumn{3}{|c|}{ Lactose hydrolysis } & $\begin{array}{c}\text { Oligosaccharides }^{2} \\
(\mathrm{~g} / \mathrm{L})\end{array}$ \\
\hline 1 & 4.5 & 19 & 40 & 0.1 & 100.00 & 99.89 & 0.11 & 0.0679 \\
\hline 2 & 7.0 & 19 & 40 & 0.1 & 63.10 & 66.07 & -4.71 & 0.0759 \\
\hline 3 & 4.5 & 45 & 40 & 0.1 & 100.00 & 104.57 & -4.57 & 0.0707 \\
\hline 4 & 7.0 & 45 & 40 & 0.1 & 69.34 & 70.75 & -2.03 & 0.0768 \\
\hline 7 & 4.5 & 45 & 50 & 0.1 & 100.00 & 104.57 & -4.57 & 0.0825 \\
\hline 8 & 7.0 & 45 & 50 & 0.1 & 77.25 & 70.75 & 8.42 & 0.0845 \\
\hline 9 & 4.5 & 19 & 40 & 0.2 & 100.00 & 99.57 & 0.43 & 0.0697 \\
\hline 10 & 7.0 & 19 & 40 & 0.2 & 78.84 & 80.95 & -2.68 & 0.0686 \\
\hline 11 & 4.5 & 45 & 40 & 0.2 & 100.00 & 104.25 & -4.25 & 0.0705 \\
\hline 12 & 7.0 & 45 & 40 & 0.2 & 83.71 & 85.63 & -2.29 & 0.0764 \\
\hline 13 & 4.5 & 19 & 50 & 0.2 & 100.00 & 99.57 & 0.43 & 0.0788 \\
\hline 19 & 5.75 & 6 & 45 & 0.15 & 87.32 & 92.04 & -5.41 & 0.0637 \\
\hline 20 & 5.75 & 58 & 45 & 0.15 & 100.00 & 101.4 & -1.40 & 0.0652 \\
\hline 21 & 5.75 & 32 & 35 & 0.15 & 98.10 & 96.72 & 1.41 & 0.0630 \\
\hline 22 & 5.75 & 32 & 55 & 0.15 & 100.00 & 96.72 & 3.28 & 0.0686 \\
\hline 23 & 5.75 & 32 & 45 & 0.05 & 87.75 & 89.44 & -1.93 & 0.0654 \\
\hline 24 & 5.75 & 32 & 45 & 0.25 & 100.00 & 104 & -4.00 & 0.0627 \\
\hline 25 & 5.75 & 32 & 45 & 0.15 & 99.89 & 96.72 & 3.17 & 0.0689 \\
\hline 26 & 5.75 & 32 & 45 & 0.15 & 100.00 & 96.72 & 3.28 & 0.0657 \\
\hline 27 & 5.75 & 32 & 45 & 0.15 & 99.88 & 96.72 & 3.17 & 0.0653 \\
\hline 28 & 5.75 & 32 & 45 & 0.15 & 99.86 & 96.72 & 3.14 & 0.0650 \\
\hline Control & - & - & - & - & - & - & & 0.0612 \\
\hline Control & - & - & - & - & - & - & & 0.0560 \\
\hline
\end{tabular}

${ }^{1}$ Complete $2^{4}$ factorial design parameters, with 4 independent variables in 2 levels, 4 repetitions in the central point, and 8 axial points.

${ }^{2}$ Oligosaccharides are a sum of $3^{\prime}$-sialyllactose (SL), $6^{\prime}$-SL, and $6{ }^{\prime}$-sialyl- $N$-acetyllactosamine $\left(6^{\prime}\right.$-SLN). All samples were analyzed in triplicate.

necessary to completely hydrolyze human milk lactose using $\beta$-galactosidase from A. oryzae at pH 5.2 (Sarney et al., 2000), but the lactose concentration difference between human milk and our starting material (69-72 vs. $\sim 18 \mathrm{~g} / \mathrm{L}$, respectively) must be considered.

Because of their biological relevance, the stability of sialic acid compounds under acidic and alkaline processing conditions has been investigated since the early 1960s. The limited information regarding their stability in the literature is likely a consequence of the complexity associated with the many derivative forms of sialic acid or the way in which sialic acid can be linked to another molecule. Additionally, one must consider the limitations associated with previously used colorimetric methods that are hampered by interference from reaction products and other molecules in the medium (Karkas and Chargaff, 1964). Recent advances in carbohydrate analysis as well as the availability of commercial standards for many milk sialyloligosaccharides have enabled a new level of accurate quantification of those compounds (Lange et al., 2014).
Our results demonstrate that the total amount of sialyloligosaccharides was not significantly altered by the reaction parameters used in any of the 28 experimental conditions. Although small variations $(0.0525-0.0848$ $\mathrm{g} / \mathrm{L} ; \mathrm{CV}<10 \%)$ in the total amount of sialyloligosaccharides were observed within the 28 experimental conditions tested, the absence of statistical significance among the results obtained demonstrates the specificity of the $\beta$-galactosidase used toward lactose. Importantly, the reaction parameters (time, temperature, and $\mathrm{pH}$ ) used in this experiment did not degrade the sialyloligosaccharides. The total amount of sialyloligosaccharides in all experimental conditions is very similar to the oligosaccharide content of the control sample $(0.0586 \mathrm{~g} / \mathrm{L} ; \mathrm{CV}=6.27 \%)$. Our quantitative results are in good agreement with those presented by Karkas and Chargaff (1964), who investigated the labile nature of the glycosidic link of sialic acid under different $\mathrm{pH}$ values and holding times $(10-60 \mathrm{~min})$ at $100^{\circ} \mathrm{C}$. In their study, no appreciable hydrolysis of the glycosidic link of methoxysialic acid was observed at $\mathrm{pH} 5$ to 7 , 
with moderate cleavage being observed at $\mathrm{pH}$ 4.0. Fast rupture of the glycosidic link (without degradation of released sialic acid) was observed at $\mathrm{pH}$ 3.0. Our results demonstrate that complete lactose hydrolysis can be rapidly achieved at different processing conditions $(\mathrm{pH}$ $4.5-5.75,35-55^{\circ} \mathrm{C}, 19-58 \mathrm{~min}$, and $0.10-0.25 \%$ enzyme) without any detrimental effect on the target sialyloligosaccharides. The low temperature range used in our study $\left(35-55^{\circ} \mathrm{C}\right.$ vs. $\left.100^{\circ} \mathrm{C}\right)$ likely protected the acidic oligosaccharides at $\mathrm{pH} 4.5$, with no observable reductions in the amount of oligosaccharides.

\section{Statistical Analysis for Lactose Hydrolysis Optimization and Preservation of Sialyloligosaccharides}

The optimum level for each independent variable evaluated was determined by multiple regression analysis of the experimental data. The estimated regression model and the coefficient of determination $\left(\mathrm{R}^{2}\right)$ for lactose hydrolysis from bovine colostrum whey permeate by $\beta$-galactosidase were determined using parameters significant at $P<0.05$. The regression equation of second order shows the dependence of the lactose hydrolysis to $\mathrm{pH}$, time, and amount of enzyme:

$$
\begin{aligned}
Y_{1} & =96.76-13.16 X_{1}-7.75 X_{1}^{2}+2.38 X_{2}+3.60 X_{4} \\
& +3.86 X_{1} X_{4},
\end{aligned}
$$

where $Y_{1}$ is the dependent variable, lactose hydrolysis (\%), and $X_{1}, X_{2}$, and $X_{4}$ are the independent variables $\mathrm{pH}$, time, and amount of enzyme, respectively. The coefficient of determination $\left(\mathrm{R}^{2}\right)$ of the predictive model for lactose hydrolysis from bovine colostrum whey permeate by $\beta$-galactosidase was 0.9398 , indicating that the regression model was able to explain $93.98 \%$ of the total variation between the observed and predicted values and the remaining $6.02 \%$ being attributed to the residual values. According to the model, complete lactose hydrolysis can be achieved at $\mathrm{pH} 4.5(-1)$, reaction time of $45 \mathrm{~min}(1)$, and amount of enzyme as low as $0.10 \%(-1)$, respectively. Alternately, complete lactose hydrolysis could also be achieved at higher $\mathrm{pH}$ (5.75). At higher $\mathrm{pH}$, longer reaction time (58 min) or a greater amount of enzyme (0.25\%) are needed to ensure complete lactose hydrolysis. The independent variable temperature was not statistically significant in the range evaluated $\left(35-55^{\circ} \mathrm{C}\right)$, thus the lowest temperature value could be used to achieve complete lactose hydrolysis.

The ANOVA of the estimated regression model is presented in Table 3. The regression was significant $\left(\mathrm{F}_{\text {calculated }}>\mathrm{F}_{\text {table }}\right)$ and thus could be used for predictive goals in the range of parameters evaluated since the
Table 3. Analysis of variance of the estimated model for the hydrolysis of lactose from bovine colostrum whey by $\beta$-galactosidase ${ }^{1}$

\begin{tabular}{lrrrr}
\hline Source of variation & Sum of squares & df & Mean squares & F-test \\
\hline Regression & $6,487.5$ & 5 & $1,297.5$ & $68.7^{*}$ \\
Residual & 415.6 & 22 & 18.9 & \\
Lack of fit & 415.6 & 19 & 21.9 & $5,526.1^{*}$ \\
Pure error & 0.0 & 3 & 0.0 & \\
Total & $6,903.2$ & 27 & & \\
\hline
\end{tabular}

${ }^{1} \mathrm{R}^{2}=0.9398 ; \mathrm{F}_{0.95-5.22}=2.66 ; \mathrm{F}_{0.95-19.3}=8.66$.

$* P<0.05$

ratio $\mathrm{F}_{\text {calculated }} / \mathrm{F}_{\text {table }}$ is greater than 3 (Rodrigues and Iemma, 2014). Although the F-test for the lack of fit was statistically significant $\left(\mathrm{F}_{\text {calculated }}>\mathrm{F}_{\text {table }}\right)$, a careful interpretation of the ANOVA results is necessary. In fact, the model has a very low lack of fit [(415.6/6903.2) $\times 100=6.02 \%]$. However, its significance is associated with a pure error that tends toward zero, which is a consequence of the high reproducibility of the repetitions performed in the central point $(99.89,100,99.88$, and 99.86). When calculating the F-test for the lack of fit, the ratio of the mean square of the lack of fit (21.9) by the mean square of the pure error (0.0) generates a high value for the F-test that could be confounding and should not be misinterpreted. As presented in Table 2, experimental and predicted values are very comparable, with very low values of the relative error $(<5 \%)$ under experimental conditions in which lactose hydrolysis is favored.

Based on the estimated regression model generated, response surfaces were built to express the hydrolysis of lactose from whey permeate by $\beta$-galactosidase (Figure $1 \mathrm{~A}-\mathrm{C})$. All response surfaces were built with the fixed variable in the central point (0). Because the variable temperature was not statistically significant, it was not used to generate the estimated regression model and response surfaces. According to the estimated regression model and Figure $1(\mathrm{~A}-\mathrm{B})$, the variable $\mathrm{pH}$ had a more pronounced effect on the hydrolysis of lactose compared with other operational parameters (time and amount of enzyme). A low $\mathrm{pH}$ range (3.25-4.5) was a requirement for maximum lactose hydrolysis. Based on the estimated regression model and Figure 1A, greater lactose hydrolysis is observed at reaction times longer than 19 min and $\mathrm{pH}$ values around 4.5. According to the estimated regression model and Figure 1B, lactase efficiency was favored at $\mathrm{pH}$ values from 3.25 to 4.5 , requiring a higher concentration of enzyme to achieve maximum lactose hydrolysis at $\mathrm{pH}$ ranging from 4.5 to 5.75. Based on the estimated regression model and Figure 1C, greater lactose hydrolysis is obtained at a reaction time longer than $45 \mathrm{~min}$ and an enzyme concentration higher than $0.2 \%$. Optimized values of $\mathrm{pH}$, 
BELL ET AL.
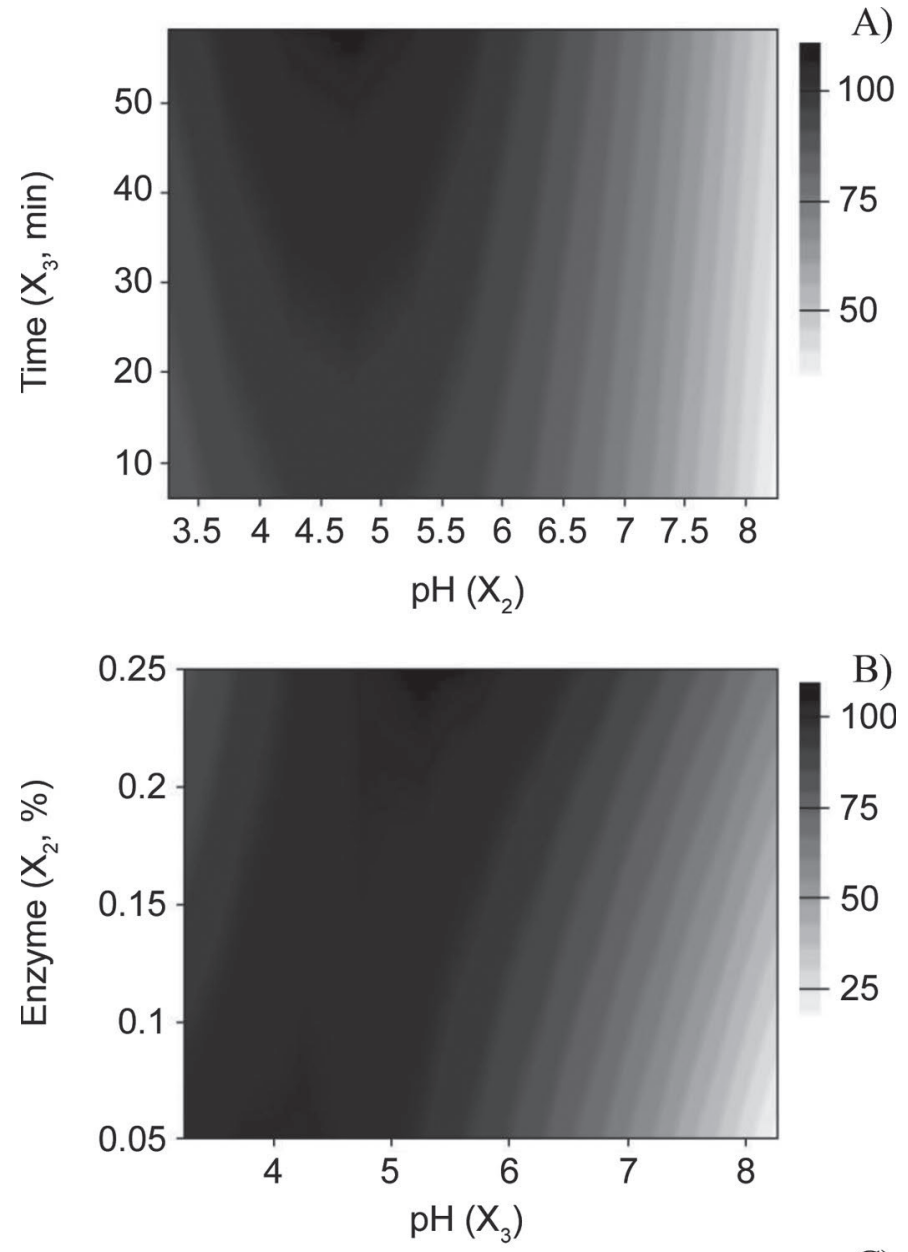

B)

$-100$

$-75$

$-50$ $-25$

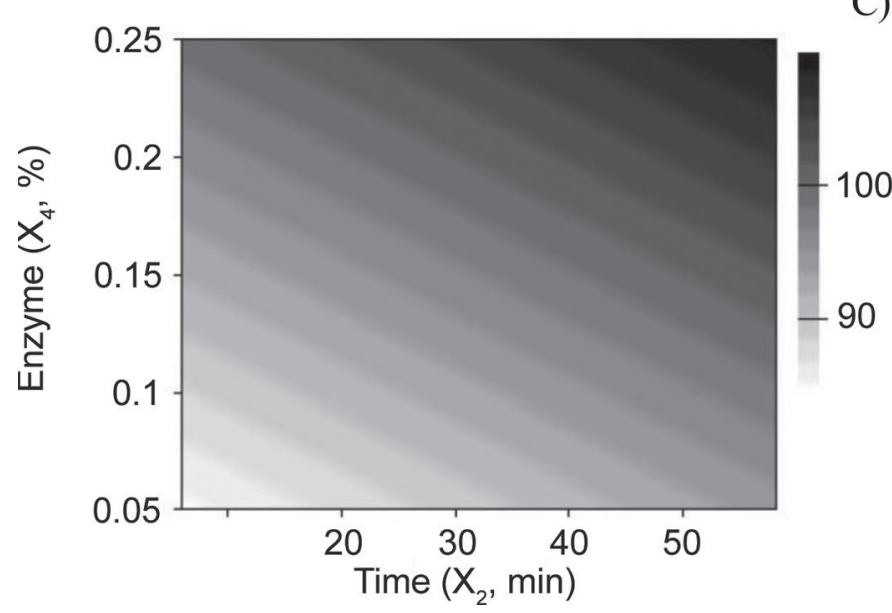

Figure 1. Effects of processing parameters on lactose hydrolysis efficiency by $\beta$-galactosidase: (A) reaction time versus $\mathrm{pH}$, (B) amount of enzyme versus $\mathrm{pH}$, and $(\mathrm{C})$ amount of enzyme versus reaction time.

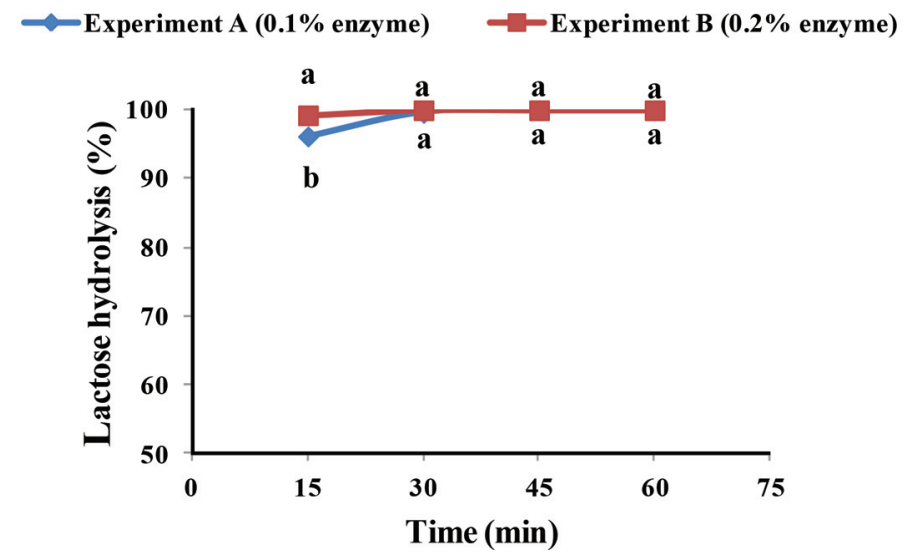

Figure 2. Validation of the predictive model at laboratory scale. Averages of triplicate followed by the same letters are not statistically different at $P<0.05$. Color version available online.

amount of enzyme, and reaction time could be used with any evaluated temperature $\left(35-55^{\circ} \mathrm{C}\right)$.

\section{Validation of the Predictive Model at Laboratory Scale}

To validate the predictive model for lactose hydrolysis by $\beta$-galactosidase, 2 sets of experiments, using 0.1 and $0.2 \%$ of enzyme, were conducted in triplicate (Figure 2). Experiments were conducted at $50^{\circ} \mathrm{C}$ and $\mathrm{pH} 4.5$. The reaction kinetics were evaluated, with samples being withdrawn at 15-min intervals for $1 \mathrm{~h}$. A $t$-test was

C) used to verify if the 2 sets of data were statistically different at each time point. Lactose hydrolysis efficiency was 96.1 and $99.3 \%$ at 15 min of reaction when 0.1 and $0.2 \%$ of enzyme was used, respectively (statistically different at $P<0.05$ ). No statistical difference was observed between the 2 sets of experiments beyond $30 \mathrm{~min}$ of reaction. Those results are in good agreement with the predictive model statement that complete lactose hydrolysis could be achieved at $\mathrm{pH} 4.5$, a reaction time of $45 \mathrm{~min}$, and an amount of enzyme as low as $0.10 \%$. Thus, the developed model is reliable and accurate for the prediction of lactose hydrolysis by $\beta$-galactosidase.

\section{CONCLUSIONS}

Lactose hydrolysis by $\beta$-galactosidase was profoundly affected by $\mathrm{pH}$ values, with lower $\mathrm{pH}$ values favoring lactose hydrolysis. Complete lactose hydrolysis was achieved at $\mathrm{pH}$ values ranging from 3.25 to 5.75 . The regression model allows for the use of possible combinations of the reaction parameters that lead to maximum lactose hydrolysis without requiring very low $\mathrm{pH}$ values such as 3.25. Complete lactose hydrolysis can be achieved at $\mathrm{pH} 4.5$, a reaction time of $45 \mathrm{~min}$, and 
an amount of enzyme as low as $0.10 \%$. Alternately, complete lactose hydrolysis could also be achieved at a higher $\mathrm{pH}$ (5.75). At a higher $\mathrm{pH}$, a longer reaction time $(58 \mathrm{~min})$ or a greater amount of enzyme $(0.25 \%)$ is needed to ensure complete lactose hydrolysis. This aspect is of practical importance given that the initial $\mathrm{pH}$ of our starting material was around 6.0. Lactose hydrolysis was not significantly affected by temperature in the range evaluated, indicating that maximum lactose hydrolysis can be achieved at a temperature as low as $35^{\circ} \mathrm{C}$. Total sialyloligosaccharide concentrations were not significantly altered either by $\beta$-galactosidase or by temperature, reaction time, and $\mathrm{pH}$. The processing conditions enabling complete lactose hydrolysis also enable the preservation of naturally present bioactive oligosaccharides in bovine colostrum.

\section{ACKNOWLEDGMENTS}

This work was supported by the Bill and Melinda Gates Foundation (Seattle, WA); National Institutes of Health (Bethesda, MD) awards R21AT006180, R01AT007079, and R01 AT008759; and the Peter J. Shields Endowed Chair in Dairy Food Science (Davis, CA).

\section{REFERENCES}

Barile, D., M. Marotta, C. Chu, R. Mehra, R. Grimm, C. B. Lebrilla, and J. B. German. 2010. Neutral and acidic oligosaccharides in Holstein-Friesian colostrum during the first 3 days of lactation measured by high performance liquid chromatography on a mi- crofluidic chip and time-of-flight mass spectrometry. J. Dairy Sci. 93:3940-3949. http://dx.doi.org/10.3168/jds.2010-3156.

Barile, D., and R. A. Rastall. 2013. Human milk and related oligosaccharides as prebiotics. Curr. Opin. Biotechnol. 24:214-219. http:// dx.doi.org/10.1016/j.copbio.2013.01.008.

Barile, D., N. Tao, C. B. Lebrilla, J.-D. Coisson, M. Arlorio, and J. B. German. 2009. Permeate from cheese whey ultrafiltration is a source of milk oligosaccharides. Int. Dairy J. 19:524-530. http:// dx.doi.org/10.1016/j.idairyj.2009.03.008.

Czermak, P., M. Ebrahimi, K. Grau, S. Netz, G. Sawatzki, and P. H. Pfromm. 2004. Membrane-assisted enzymatic production of galactosyl-oligosaccharides from lactose in a continuous process. J. Membr. Sci. 232:85-91. http://dx.doi.org/10.1016/j. memsci.2003.11.024

Hatzinikolaou, D. G., E. Katsifas, D. Mamma, A. D. Karagouni, P. Christakopoulos, and D. Kekos. 2005. Modeling of the simultaneous hydrolysis-ultrafiltration of whey permeate by a thermostable $\beta$-galactosidase from Aspergillus niger. Biochem. Eng. J. 24:161172. http://dx.doi.org/10.1016/j.bej.2005.02.011.

Jelen, P. 1979. Industrial whey processing technology: an overview. J. Agric. Food Chem. 27:658-661. http://dx.doi.org/10.1021/ jf60224a037.

Karkas, J. D., and E. Chargaff. 1964. Studies on the stability of simple derivatives of sialic acid. J. Biol. Chem. 239:949-957.

Lange, M., H. Lee, D. Dallas, A. Le Parc, J. M. L. N. de Moura Bell, and D. Barile. 2014. Determining functional properties and sources of recently identified bioactive food components: oligosaccharides, glycolipids, glycoproteins, and peptides. Pages 441-461 in Encyclopedia of Agriculture and Food Systems. Elsevier, San Diego, CA.

Martín-Sosa, S., M.-J. Martín, L.-A. García-Pardo, and P. Hueso. 2003. Sialyloligosaccharides in human and bovine milk and in infant formulas: Variations with the progression of lactation. J. Dairy Sci. 86:52-59. http://dx.doi.org/10.3168/jds.S0022-0302(03)73583-8.

Rodrigues, M. I., and A. F. Iemma. 2014. Experimental Design and Process Optimization. CRC Press, Boca Raton, FL.

Sarney, D. B., C. Hale, G. Frankel, and E. N. Vulfson. 2000. A novel approach to the recovery of biologically active oligosaccharides from milk using a combination of enzymatic treatment and nanofiltration. Biotechnol. Bioeng. 69:461-467. http://dx.doi. org/10.1002/1097-0290(20000820)69:4<461:aid-bit13>3.0.co;2-l. 